Article

\title{
Cover Crop for a Sustainable Viticulture: Effects on Soil Properties and Table Grape Production
}

\author{
Concetta Eliana Gattullo ${ }^{1, *}$, Giuseppe Natale Mezzapesa ${ }^{2}$, Anna Maria Stellacci ${ }^{1}$, \\ Giuseppe Ferrara ${ }^{1}$, Giuliana Occhiogrosso ${ }^{1}$, Giuseppe Petrelli ${ }^{1}$, Mirko Castellini ${ }^{3}$ (D) and \\ Matteo Spagnuolo ${ }^{1}$ (D) \\ 1 Department of Soil, Plant and Food Sciences, University of Bari “A. Moro”, 70126 Bari, Italy; \\ annamaria.stellacci@uniba.it (A.M.S.); giuseppe.ferrara@uniba.it (G.F.); g-occhiogrosso@hotmail.it (G.O.); \\ giu.petrelli@libero.it (G.P.); matteo.spagnuolo@uniba.it (M.S.) \\ 2 Mediterranean Agronomic Institute of Bari (C.I.H.E.A.M.), 70010 Valenzano, Italy; mezzapesa@iamb.it \\ 3 Council for Agricultural Research and Economics-Agriculture and Environment Research \\ Center (CREA-AA), 70126 Bari, Italy; mirko.castellini@crea.gov.it \\ * Correspondence: concettaeliana.gattullo@uniba.it
}

Received: 25 July 2020; Accepted: 3 September 2020; Published: 5 September 2020

\begin{abstract}
Cover crops are increasingly adopted in viticulture to enhance soil quality and balance the vegetative and reproductive growth of vines. Nevertheless, this sustainable practice has been only recently used for table grape viticulture, with results often contrasting. The aim of this study was to assess the effect of a fescue (Festuca arundinacea Schreb.) cover crop on soil quality, yield, and grape qualitative parameters in a table grape vineyard (cv "Italia") located in southern Italy, comparing results with the conventional tillage. Soil organic carbon $(\mathrm{C})$, total nitrogen $(\mathrm{N})$, microbial biomass $\mathrm{C}$ (MBC), $\beta$-glucosidase (BGLU) and alkaline phosphomonoesterase (APME) activities were assessed during three growing seasons (2012-2014) and three phenological stages. The trend of soil chemical and microbiological properties was jointly influenced by the soil management system, growing season and phenological stage. Compared to conventional tillage, cover crops increased, on average, soil organic C, total N, MBC, BGLU and APME by $136 \%, 93 \%, 112 \%, 100 \%$ and $62 \%$, respectively. Slight or no effects of cover crops were observed on grape quality and yield, except for 2012 (the driest season), when a yield reduction occurred. This study reveals that cover crops strongly enhance soil quality in the short-term, with potential advantages for grape production in the long-term.
\end{abstract}

Keywords: Vitis vinifera; fescue cover crop; carbon sequestration; soil quality; soil microbial biomass; $\beta$-glucosidase; alkaline phosphomonoesterase; grape quality

\section{Introduction}

Grapevine (Vitis vinifera L.) is one of the main fruit crops cultivated all over the world, with a global production of 73.1 million tons of fresh grapes in 2018, including 23.5 million tons of table grapes [1,2]. Vineyard management practices have been continuously intensified in the last decades, as proved by the gradual increase of the world grape production despite the global decline of the world vine area, starting from the early 2000s [1]. Crop intensification, although increasing yields, lowers soil fertility and biodiversity due to the excessive exploitation of natural resources, massive introduction of external inputs and substantial alteration of agroecosystem equilibria.

Soil is a heterogeneous, dynamic and non-renewable system, which plays a key role for delivering ecosystem services, such as the biomass production, carbon sequestration, nutrient storage and cycling, water retention and filtration, climate mitigation, and preservation of biodiversity [3]. Among these functions, carbon sequestration is crucial for the mitigation of greenhouse gas emission and preservation 
of soil fertility. Soil is the main terrestrial organic carbon pool, storing three and four times more carbon than the atmosphere and the aboveground vegetation, respectively [4]. Organic matter favors the aggregation of soil particles and preservation of soil structure, retention of nutrients and water, enhancement of hydraulic soil properties, and maintenance of soil trophic relations, and slight variations of its content may seriously affect the soil quality. Thus, several policies, including the Common Agricultural Policy (CAP) of the European Union, strongly encourage the use of soil conservative practices aimed at increasing, or at minimum preserving, the organic matter content of soils [5].

Sustainable viticulture should balance the protection and enhancement of environmental resources with high-quality grape production and economic profitability [6]. Among the sustainable practices implemented in the last decades, the use of cover crops is still controversial. Cover crops enrich the soil with organic matter, reduce water runoff and nutrient leaching, limit erosion processes, stimulate biological activity, especially that of microbes and earthworms, enrich the soil with nitrogen when leguminous species are used, and suppress weeds [7]. Vegetation crops also improve soil physical properties. Indeed, organic matter derived from cover crops may favor the formation and stabilization of soil aggregates, and roots of cover crops may directly improve the soil structure $[8,9]$. The presence of earthworm-produced pores and channels in the soil is also favored under cover cropping, with positive implications on the soil permeability and porosity [9]. On the other hand, cover crops may compete with vines for water and nutrients such that, especially in semiarid countries, farmers prefer to use temporary cover crops and leave the soil bare during summer $[5,10]$.

The effects of cover crops in viticulture can be very variable and contrasting, depending on the soil properties, type of cover crop, climate conditions and management practices. To unravel this issue, soil quality parameters indicative of the different soil management should be selected and monitored. A number of studies are reported in the literature about the evaluation of microbial biomass, enzymatic activities and other biochemical parameters as indicators of soil quality under different management systems [11-14]. However, few studies focus on the vineyard system [15-17], and none of them deal with table grape vineyards.

In this research, the effects of a fescue (Festuca arundinacea Schreb.) cover crop on soil properties and grape production were investigated in a table grape vineyard of the Mediterranean area and compared with conventional soil management. A number of soil chemical and microbiological properties were assessed during three growing seasons and in different phenological stages, in order to evaluate the effects of different soil management systems on soil quality.

\section{Materials and Methods}

\subsection{Experimental Site}

The study was carried out during three growing seasons (2012, 2013 and 2014) in a table grape vineyard located in southern Italy (San Ferdinando di Puglia, $41^{\circ} 19^{\prime} 09.47^{\prime \prime} \mathrm{N} 16^{\circ} 05^{\prime} 33.17^{\prime \prime}$ E), on Vitis vinifera L. cv "Italia" grafted on 140 Ru rootstock. Vines were planted in 2006 and trained by an overhead trellis system (known as 'tendone'), at a distance of $2.3 \mathrm{~m} \times 2.3 \mathrm{~m}$. Pruning was performed leaving four fruiting canes per plant, with ten buds per cane. The vineyard was irrigated using a drip irrigation system and a water volume ranging between 1800 and $2300 \mathrm{~m}^{3} \mathrm{ha}^{-1}$ year ${ }^{-1}$, depending on the annual climatic trend. A randomized complete block design was adopted, with two treatments corresponding to two different soil management systems: a permanent cover crop of fescue, sown starting from 2009, and conventional soil tillage (used as control). The cover crop was sown both within the rows and in the inter-rows, at a density of $50 \mathrm{~kg} \mathrm{ha}^{-1}$. It was mowed four times a year, between the end of February and the beginning of June. After mowing, grass residues were left on the ground. The soil under conventional tillage was subjected to four tillage passes from March to June at $0-10 \mathrm{~cm}$ depth, as the weed control required, and deeper soil tillage $(0-20 \mathrm{~cm}$ depth $)$ in the autumn-winter season. All the other management practices, including fertilization and pest control, were similar between the two treatments and comparable to the standard agronomical practices adopted in the 
surrounding vine area. Fertilizer doses of $70 \mathrm{~kg}$ of nitrogen $(\mathrm{N}), 50 \mathrm{~kg}$ of phosphorus $(\mathrm{P})$ and $100 \mathrm{~kg}$ of potassium $(\mathrm{K})$ were applied per hectare. Each treatment was replicated three times, with one replicate per block. Each replicate consisted of three rows with 25 vines per row.

A typical Mediterranean climate, characterized by moderately cold and rainy winters, and hot and dry summers, was present in the experimental area. Data of rainfall and temperatures measured in the agrometeorological station closest to the experimental site (placed at a distance of $2.5 \mathrm{~km}$ ) are shown in Figure 1.

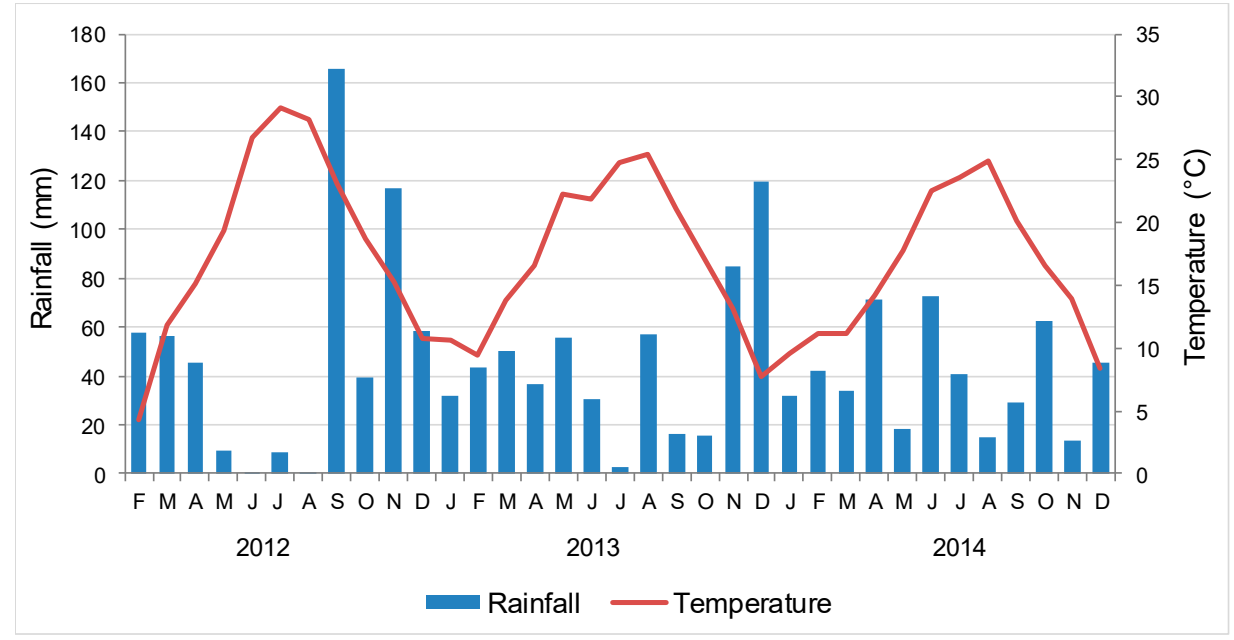

Figure 1. The trend of total rainfall and mean temperature between February 2012 and December 2014 in the investigated area.

\subsection{Soil Sampling and Characterization}

Soil was sampled during three vine phenological stages: flowering (May), fruit growth (July), and ripening (August). A representative soil sample was taken for each treatment and each replicate at $0-20 \mathrm{~cm}$ depth, in the inter-row and intra-row spaces. Then, each soil sample was split into two parts: a part was air-dried, gently homogenized in a porcelain mortar with a pestle and used for the physicochemical analyses, whereas the other part was roughly sieved at $2 \mathrm{~mm}$ and immediately stored at $4{ }^{\circ} \mathrm{C}$ for the microbiological analyses.

Soils were characterized for the following physicochemical properties: texture [18], $\mathrm{pH}$ (both in $\mathrm{H}_{2} \mathrm{O}$ and in a $\mathrm{CaCl}_{2}$ solution, using in both cases a soil/solution ratio of $1: 2.5, \mathrm{~m} / \mathrm{v}$ ), electrical conductivity (EC), organic $\mathrm{C}$ content (Walkley-Black method), total $\mathrm{N}$ content (Kjeldahl method), total and active $\mathrm{CaCO}_{3}$ [19], and available $\mathrm{P}$ (Olsen method). All the chemical analyses, except for texture and $\mathrm{CaCO}_{3}$ determination, were carried out following the standard procedures for soil analyses reported by Sparks [20].

Soil microbial biomass $\mathrm{C}$ (MBC) was measured through the fumigation-incubation-extraction method [21]. Each field-moist soil sample (containing $50 \mathrm{~g}$ oven-dried soil) was divided in half: a non-fumigated half (control) was immediately extracted with $100 \mathrm{~mL} 0.5 \mathrm{M} \mathrm{K}_{2} \mathrm{SO}_{4}$ for $30 \mathrm{~min}$, whereas the remaining part was fumigated with chloroform in the dark, for $24 \mathrm{~h}$ at $25^{\circ} \mathrm{C}$. After fumigation, $\mathrm{CHCl}_{3}$ was removed and soil samples were extracted as indicated for the control. Organic $\mathrm{C}$ in the soil extracts was measured using the Springer-Klee method.

The $\beta$-glucosidase (BGLU) activity of soils was determined according to Eivazi and Tabatabai [22], measuring spectrophotometrically (at $400 \mathrm{~nm}$ wavelength) the amount of p-nitrophenol (PNP) released after $1 \mathrm{~h}$ of soil incubation with a p-nitrophenol- $\beta$-D glucoside solution, at $37^{\circ} \mathrm{C}$. The alkaline phosphomonoesterase (APME) activity was determined following the procedure described by Eivazi and Tabatabai [23]. Briefly, soil was added with a buffered ( $\mathrm{pH}$ 11) p-nitrophenyl phosphate solution 
and, after $1 \mathrm{~h}$ of incubation at $37^{\circ} \mathrm{C}$, the amount of PNP released as a result of the hydrolytic activity was measured spectrophotometrically at $400 \mathrm{~nm}$ wavelength.

\subsection{Yield and Grape Qualitative Parameters}

The number of clusters, plant yield and cluster mean weight per vine were determined on 60 vines per treatment (20 vines for replicate), at harvest.

The following parameters were also evaluated on a sample of 150 berries randomly selected in each treatment ( 50 berries for replicate): berry mean weight, berry firmness, pedicel detachment force, and skin colorimetric parameters. Firmness was measured on the whole berry (containing both skin and pulp) using a digital penetrometer (mod. PCE-PTR 200, PCE Italia s.r.l., Capannori, Italy) with a 2 mm-tip. The detachment force was detected by means of a manual dynamometer (mod. PCE-FM 1000, PCE Italia s.r.l., Capannori, Italy). The colorimetric parameters, namely L* (lightness), $C^{*}$ (chroma) and $h^{\circ}$ (hue), were measured at two equidistant points of the berry equatorial zone by means of a colorimeter (CR-400, Minolta, Japan). The juice extracted from grape berries was analyzed for total soluble solid content using a digital refractometer (mod. HI96814, Hanna Instruments, Woonsocket, RI, USA), as well as for $\mathrm{pH}$ and titratable acidity. The latter, expressed as tartaric acid concentration $\left(\mathrm{g} \mathrm{L}^{-1}\right)$, was measured by titration with $\mathrm{NaOH} 0.1 \mathrm{~N}$, using a semiautomatic titrator (mod. PH-Burette 24, Crison Instruments, Barcelona, Spain).

\subsection{Statistical Analysis}

Descriptive statistics were computed for the variables under study to summarize the main features of data distribution. In addition, homogeneity of variances across treatments and years was tested using Bartlett's test.

Analysis of variance was carried out considering year as a repeated measurement factor and hypothesizing a compound symmetry (CS) covariance structure for the residuals corresponding to a split-plot experimental design [24]. For the soil variables quantified over the crop season $(2012,2013$ and 2014), the repeated factor was derived from the factorial combination of year and phenological stage. Means were compared using the Student-Newman-Keuls (SNK) test at a 0.05 probability level.

\section{Results and Discussion}

\subsection{Soil Chemical and Microbiological Properties}

Physicochemical analyses carried out on soil samples collected during flowering in 2012, revealed that the soil management system does not influence soil texture, $\mathrm{pH}, \mathrm{EC}$, total and active $\mathrm{CaCO}_{3}$, and available P. Indeed, regardless of the treatment, soils possessed a silt loam texture and were moderately alkaline, non-saline, strongly calcareous, very rich in active $\mathrm{CaCO}_{3}$, but poor in available $\mathrm{P}$ (Table 1). Conversely, the soil management system strongly affected the content of organic $\mathrm{C}$, total $\mathrm{N}$ and $\mathrm{MBC}$, as well as the soil enzymatic activities. Hence, for the latter parameters, monitoring during three growing seasons (2012, 2013 and 2014) and three phenological stages (flowering, fruit growth and ripening) was performed. Nevertheless, because the trend of organic $\mathrm{C}$ and total $\mathrm{N}$ content did not vary during the three phenological stages of 2012 (data not shown), only measurements at flowering were carried out for these two parameters in 2013 and 2014.

Table 1. Physical and chemical properties of soils $(0-20 \mathrm{~cm})$ measured in 2012, at grapevine flowering. Data are expressed as mean $\pm \operatorname{SD}(n=3)$.

\begin{tabular}{|c|c|c|c|c|c|c|c|c|c|c|}
\hline \multirow[t]{2}{*}{ Treatment } & \multirow[t]{2}{*}{ Texture } & Sand & Silt & Clay & \multirow[t]{2}{*}{$\mathrm{pH}\left(\mathrm{H}_{2} \mathrm{O}\right)$} & \multirow[t]{2}{*}{$\begin{array}{c}\mathrm{pH} \\
\left(\mathrm{CaCl}_{2}\right)^{1}\end{array}$} & \multirow{2}{*}{$\begin{array}{c}\mathrm{EC}^{2} \\
\left(\mathrm{dS} \mathrm{m} \mathrm{m}^{-1}\right)\end{array}$} & $\begin{array}{c}\text { Total } \\
\mathrm{CaCO}_{3} \\
\end{array}$ & $\begin{array}{l}\text { Active } \\
\mathrm{CaCO}_{3} \\
\end{array}$ & \multirow{2}{*}{$\begin{array}{c}\text { Olsen } \\
\text { Phosphorus } \\
\left(\mathrm{mg} \mathrm{kg}^{-1}\right)\end{array}$} \\
\hline & & & $\left.\mathrm{g} \mathrm{kg}^{-1}\right)$ & & & & & \multicolumn{2}{|c|}{$\left(\mathrm{g} \mathrm{kg}^{-1}\right)$} & \\
\hline Conventional tillage & Silt loam & $343 \pm 77$ & $573 \pm 76$ & $84 \pm 1$ & $8.2 \pm 0.3$ & $7.7 \pm 0.2$ & $0.18 \pm 0.01$ & $498 \pm 127$ & $104 \pm 8$ & $12 \pm 2$ \\
\hline Cover crop & Silt loam & $292 \pm 91$ & $630 \pm 29$ & $78 \pm 4$ & $8.3 \pm 0.1$ & $7.7 \pm 0.02$ & $0.18 \pm 0.02$ & $602 \pm 16$ & $91 \pm 4$ & $15 \pm 4$ \\
\hline
\end{tabular}


Use of cover crops significantly $(p<0.05)$ increased the content of organic $C$ in soil (Table 2; Figure 2a). Compared to the conventional tillage, cover crops produced an average increase of organic C content of $136 \%$. This value was considerably higher than that found by Tarricone et al. [25], who measured a 33\% increase after two years of cover cropping in a Mediterranean vineyard, although starting from a higher initial organic $C$ content in the bare soil $\left(17.3 \mathrm{~g} \mathrm{~kg}^{-1}\right.$, against $2.6 \mathrm{~g} \mathrm{~kg}^{-1}$ of our study). Moreover, the more prolonged duration of cover crops in our study (up to six years) was responsible for the higher organic $C$ accumulation in soil, as also evidenced by Fourie [26]. Values of organic C enrichment higher than $136 \%$ are reported in the literature for vineyards exposed to permanent cover crops, for instance, increases up to $163 \%$ and $216 \%$ of organic $C$ were measured in the topsoil $(0-5 \mathrm{~cm})$ after ten and five years of cover cropping, respectively $[16,26,27]$. Besides the soil management, the year $(p<0.01)$ and its interaction with the treatment $(p<0.05)$ significantly affected the soil organic $C$ (Table 2). A higher organic $C$ content was detected in 2013, especially under cover crops (Figure 2a). The higher rainfall amount during the autumn-winter season between 2012 and 2013 (Figure 1) might have stimulated the production of fescue biomass, thus enriching soil organic matter.

Table 2. Effect of the soil management system (treatment), growing season (year) and their interaction (treatment $\times$ year) on organic $\mathrm{C}$ and total $\mathrm{N}$ content of soil.

\begin{tabular}{ccc}
\hline & $\begin{array}{c}\text { Organic Carbon } \\
\left(\mathbf{g ~ k g}^{-\mathbf{1}}\right)\end{array}$ & $\begin{array}{c}\text { Total Nitrogen } \\
\left(\mathbf{g ~ k g}^{-\mathbf{1}}\right)\end{array}$ \\
\hline $\begin{array}{c}\text { Treatment } \\
\text { Conventional tillage } \\
\text { Cover crop }\end{array}$ & $2.86 \mathrm{~b}$ & $0.41 \mathrm{~b}$ \\
Year & $6.76 \mathrm{a}$ & $0.79 \mathrm{a}$ \\
2012 & & \\
2013 & $4.15 \mathrm{~b}$ & 0.58 \\
2014 & $5.82 \mathrm{a}$ & 0.61 \\
Significance & $4.47 \mathrm{~b}$ & 0.61 \\
Treatment $(\mathrm{T})$ & & \\
Year $(\mathrm{Y})$ & $0.0145^{*}$ & $0.0010^{* *}$ \\
T $\times \mathrm{Y}$ & $0.0016^{* *}$ & $0.2511^{\mathrm{ns}}$ \\
\hline
\end{tabular}

${ }^{1}$ Significant at $p<0.05\left({ }^{*}\right)$ and $p<0.01\left({ }^{* *}\right)$; not significant $\left({ }^{\text {ns }}\right)$. Figures in columns followed by the same letter are not statistically different according to SNK test $(p<0.05)$.

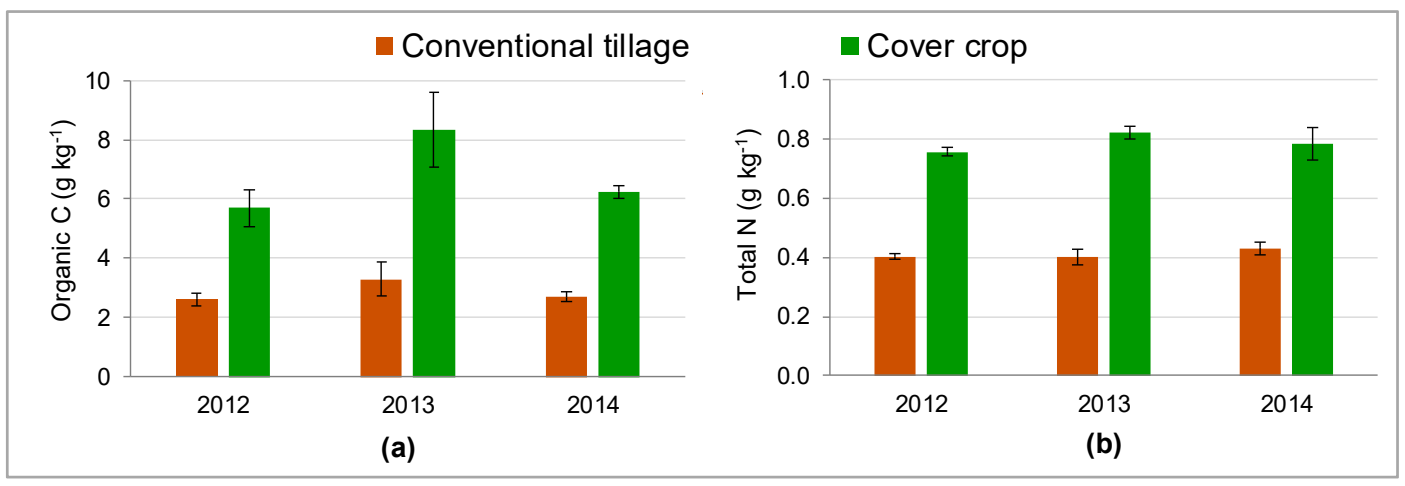

Figure 2. The trend of organic carbon (a) and total nitrogen (b) content of soil subjected to conventional tillage or cover crop during three years of experimentation. The bar on each column indicates the standard deviation $(n=3)$.

The trend of the total $N$ content was similar to that of organic $C$ content (Figure 2a,b), with a significant $(p<0.01)$ increase of the total $\mathrm{N}$ in the presence of cover crop (Table 2). Fescue, although a non-leguminous species, may contribute to create an organic $\mathrm{N}$ pool which can be slowly mineralized, releasing plant-available $\mathrm{N}$. Moreover, the presence of the cover crop might reduce the $\mathrm{N}$ loss by 
leaching, as evidenced by the lower nitrate concentration in soil water extracts observed in 2012 (data not shown). Thus, a long-term effect of cover crops may be the abatement of $\mathrm{N}$ fertilization, with environmental and economic benefits.

Soil management, year and phenological stage, as well as all their binary interactions significantly affected the soil MBC (Table 3). As for the effects of treatment $\times$ year interaction $(p<0.001)$, a higher ratio between MBC under cover crops and MBC in bare soil was observed in 2013 (namely, 2.9 against 1.9 and 1.6 measured in 2012 and 2014, respectively) (Figure 3). The major organic $C$ accumulation found in 2013 in soil subjected to cover crops (Figure 2a) might have caused an acceleration of the microbial population growth. Soil organic $C$ is the main substrate for soil microorganisms, thus its enhancement is strictly connected to the improvement of soil microbial biomass and other microbiological properties [16]. The influence of the interaction year $\times$ stage on $\mathrm{MBC}$ was also highly significant $(p<0.001)$, but difficult to unravel. It is well-known that comparison of soil MBC between different years and seasons is highly problematic, due to the frequent fluctuations of those parameters mainly influencing the soil microbial populations, namely the availability of organic substrates, the soil moisture and temperature $[28,29]$. The interaction treatment $\times$ stage also had a significant effect on MBC, although to a lesser extent $(p<0.05$; Table 3). In particular, discrepancies between MBC values under cover crop and those under conventional tillage tended to reduce during ripening (Figure 3).

Table 3. Effect of the soil management system (treatment), growing season (year), phenological phase (stage), and all their interactions on microbial biomass $C, \beta$-glucosidase (BGLU) and alkaline phosphomonoesterase (APME) activity of soil.

\begin{tabular}{|c|c|c|c|}
\hline \multirow[b]{2}{*}{ Treatment } & \multirow[t]{2}{*}{$\begin{array}{l}\text { Microbial Biomass } C \\
\left(\mu g g^{-1}\right)\end{array}$} & \multicolumn{2}{|c|}{$\begin{array}{c}\text { BGLU Activity } \\
\left(\mu \mathrm{g} \text { PNP }^{-1} \text { soil } \mathrm{min}^{-1}\right)\end{array}$} \\
\hline & & & \\
\hline Conventional tillage & $114.45 \mathrm{~b}$ & $7.45 \mathrm{~b}$ & $25.82 b$ \\
\hline Cover crop & 242.17 a & $14.56 \mathrm{a}$ & $41.93 \mathrm{a}$ \\
\hline \multicolumn{4}{|l|}{ Year } \\
\hline 2012 & $148.35 \mathrm{~b}$ & $10.02 \mathrm{~b}$ & $26.72 \mathrm{~b}$ \\
\hline 2013 & $225.70 \mathrm{a}$ & $7.29 \mathrm{c}$ & $38.51 \mathrm{a}$ \\
\hline 2014 & $160.89 \mathrm{~b}$ & $15.70 \mathrm{a}$ & $36.40 \mathrm{a}$ \\
\hline \multicolumn{4}{|l|}{ Stage } \\
\hline Flowering & $111.36 \mathrm{c}$ & $9.96 \mathrm{~b}$ & 32.69 \\
\hline Fruit growth & $163.91 \mathrm{~b}$ & $10.88 \mathrm{ab}$ & 34.64 \\
\hline Ripening & $259.67 \mathrm{a}$ & $12.17 \mathrm{a}$ & 34.29 \\
\hline \multicolumn{4}{|l|}{ Significance $^{1}$} \\
\hline Treatment $(\mathrm{T})$ & $0.0033 * *$ & $0.0162 *$ & $0.0039 * *$ \\
\hline Year $(Y)$ & $<0.0001^{* * *}$ & $<0.0001^{* * *}$ & $<0.0001^{* * *}$ \\
\hline Stage (S) & $<0.0001^{* * *}$ & $0.0203 *$ & $0.2404^{\mathrm{ns}}$ \\
\hline $\mathrm{T} \times \mathrm{Y}$ & $<0.0001^{* * *}$ & $0.1852^{\mathrm{ns}}$ & $<0.0001^{* * *}$ \\
\hline $\mathrm{T} \times \mathrm{S}$ & $0.0393 *$ & $0.0406 *$ & $0.0690^{\mathrm{ns}}$ \\
\hline $\mathrm{Y} \times \mathrm{S}$ & $<0.0001^{* * *}$ & $0.0001^{* * *}$ & $0.0015^{* *}$ \\
\hline $\mathrm{T} \times \mathrm{Y} \times \mathrm{S}$ & $0.0845^{\mathrm{ns}}$ & $0.0886^{\mathrm{ns}}$ & $0.0036^{* *}$ \\
\hline
\end{tabular}

\footnotetext{
${ }^{1}$ Significant at $p<0.05\left({ }^{*}\right), p<0.01\left(^{* *}\right)$ and $p<0.001\left(^{* * *}\right)$; not significant ${ }^{\left({ }^{n s}\right)}$. Figures in columns followed by the same letter are not statistically different according to SNK test $(p<0.05)$.
} 


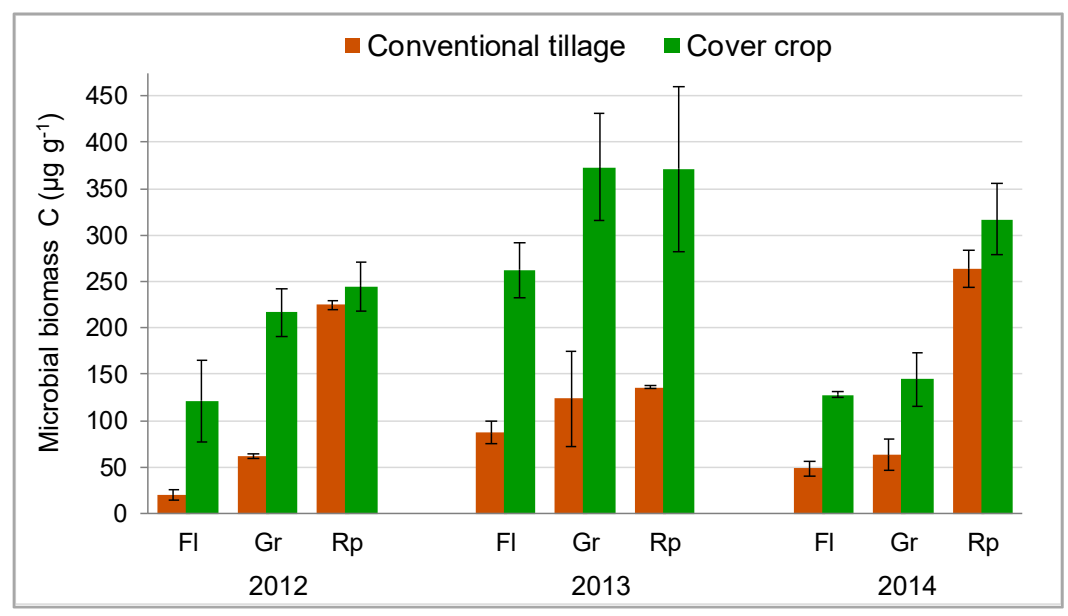

Figure 3. The trend of microbial biomass carbon of soil subjected to conventional tillage or cover crop during flowering $(\mathrm{Fl})$, fruit growth $(\mathrm{Gr})$ and ripening $(\mathrm{Rp})$ in the three years of experimentation. The bar on each column indicates the standard deviation $(n=3)$.

Cover crops significantly $(p<0.01)$ increased soil MBC by $112 \%$, on average, compared to the control (Table 3). This result was in accordance with outcomes reported by Virto et al. [15], who found an $80 \%$-increase of MBC after one and five years of permanent cover crops in a semi-arid vineyard. Explanations for the most abundant presence of microbial biomass under cover crops may be found in the higher level of soil organic $\mathrm{C}$ and total $\mathrm{N}$ of this treatment (Table 2). Similarly, Peregrina et al. [16] observed a strong correlation between the content of soil organic $C$ and MBC in vineyards subjected to cover crops. According to Gunapala and Scow [30], MBC is a better indicator of soil fertility than organic $C$ content, since an increase in $\mathrm{MBC}$ is likely to better represent changes in the nutrient-supplying capacity of organic matter, than an increase in total organic C. Cover crops also enhance the vine roots growth, compared to conventional soil management and, especially, the formation of the most active roots $(\varnothing \leq 1 \mathrm{~mm})$ [31]. Moreover, owing to the absence of any tillage pass in the cover crop plots, root biomass of both fescue and vine is concentrated in the first $20 \mathrm{~cm}$ of soil, thus contributing to the enhancement of MBC observed in the presence of cover crops. As proved by Torres et al. [32], soil dehydration occurs slower in a mulched (cover crops) table grape vineyard, with respect to the conventional tillage, therefore the higher soil humidity could have also favored the higher microbial growth under cover cropping.

The MBC was significantly influenced also by the year $(p<0.001)$, showing in 2013 an average value approximately 1.5 times higher compared to data of 2012 and 2014 (Table 3). As mentioned earlier, this result is most likely explainable by the higher organic $C$ accumulation during 2013. As for the effects of the phenological stage on MBC, a significant $(p<0.001)$ and gradual increase of this parameter was observed moving from flowering to fruit ripening. There are no studies in the literature dealing with fluctuations of microbial biomass during the growing season in the presence of cover crops. However, some hypotheses may be formulated. As is known, organic substrates, soil water content and soil temperature are the main factors driving microbial growth. The increase of soil temperature over the summer is very limited under the overhead training system ("tendone"), due to the presence of a full vegetation cover, and the soil dehydration is compensated by irrigation. Moreover, Giacometti et al. [33] observed that MBC is not affected by soil moisture fluctuations, possibly due to the method used for MBC estimation, which determines both active and inactive microbial forms. Therefore, the microbial growth in our study was mainly driven by the organic substrate availability, consisting of cover crop biomass, crop residues and root exudates. The increasing amount of soil litter over the summer, due to fescue biomass released after mowing and crop residues derived from the green pruning, and the more intense root exudation activity during ripening might have enhanced the microbial growth. 
$\beta$-glucosidase activity was significantly affected by the interactions year $\times$ stage $(p<0.001)$ and treatment $\times$ stage $(p<0.05)$, as well as by the year $(p<0.001)$, treatment $(p<0.05)$ and stage $(p<0.05)$ (Table 3). $\beta$-glucosidase is one of the most important cellulases in soil, which catalyzes the hydrolysis of carbohydrates with $\beta$-D-glucosidase-bonds, such as cellobiose, thus playing a key role in the decomposition of cellulose and C cycling [16,34]. Analogously to MBC, enzymatic activities are strongly influenced by environmental factors (substrate availability, soil moisture and temperature) fluctuating over time, thus their comparison between different years and seasons is tricky [28]. Overall, the trend of BGLU activity reflected that of MBC in 2012 and 2013, whereas it differed considerably in 2014 (Figure 4). Moreover, the enzymatic activity was significantly lower in 2013, despite the highest MBC values measured in that year (Table 3). Although a number of studies reveal that the BGLU activity is highly correlated to MBC $[15,16]$, distinct patterns of microbial biomass and extracellular enzyme activities can be observed due to enzyme immobilization on soil colloids [33]. Indeed, soil extracellular enzymes may be adsorbed on clay minerals or organic colloids, thus retaining their catalytic functions regardless of the microorganism presence [35]. The presence of cover crops significantly increased the BGLU activity of soil by approximately $100 \%$, on average (Table 3). Compared to our study, three- and nine-folds higher increases were measured by Virto et al. [15] and Peregrina et al. [16], respectively, in the topsoil $(0-5 \mathrm{~cm})$ of cover cropped vineyards. Nevertheless, Peregrina et al. [16] proved that the BGLU activity responded to the different soil management in the topsoil $(0-5 \mathrm{~cm})$, whereas only slight or negligible variations of its activity were detected in the deeper soil $(5-45 \mathrm{~cm})$. Therefore, it can be assumed that the lesser enhancement of the BGLU activity detected under cover crops in our study may be ascribed to a dilution effect that occurred in soil, due to the higher soil depth investigated $(0-20 \mathrm{~cm})$, compared to what reported in the literature.

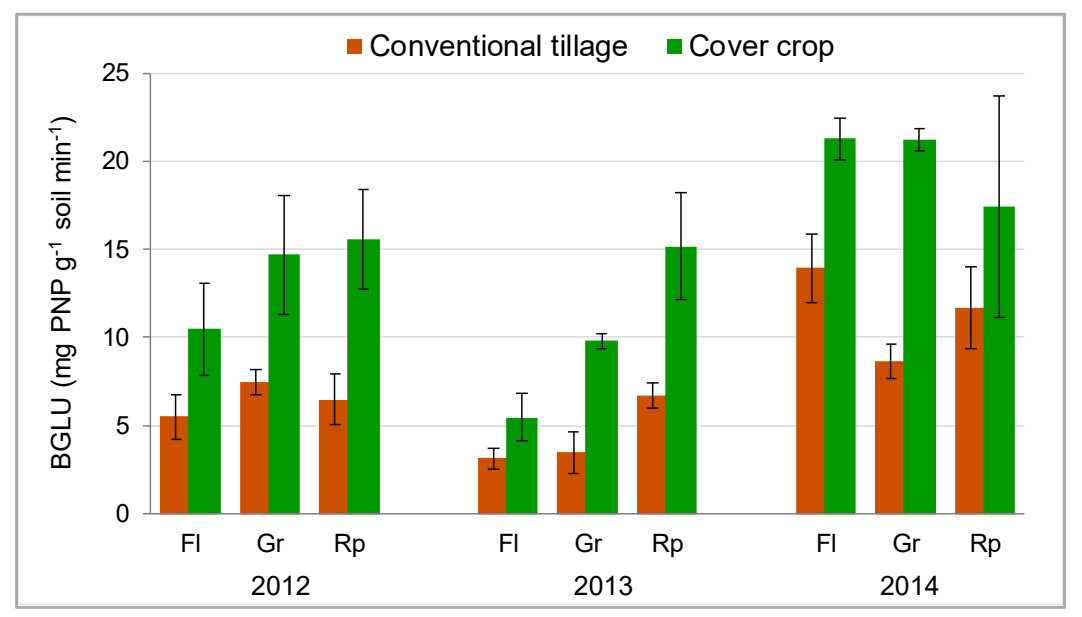

Figure 4. The trend of $\beta$-glucosidase activity (BGLU) in soil subjected to conventional tillage or cover crop during flowering $(\mathrm{Fl})$, fruit growth $(\mathrm{Gr})$ and ripening $(\mathrm{Rp})$ in the three years of experimentation. The bar on each column indicates the standard deviation $(n=3)$.

Alkaline phosphomonoesterase (APME) activity was significantly affected by the interaction treatment $\times$ year $\times$ stage $(p<0.01)$, as well as by the interactions treatment $\times$ year $(p<0.001)$ and year $\times$ stage $(p<0.01)$ (Table 3$)$. As for the interaction treatment $\times$ year, APME activity in the presence of cover crops was always higher than that measured in the bare soil, to a greater extent in 2013 than in 2012 and 2014 (Figure 5). This result may be related to the higher MBC and organic C content found in the cover-cropped soil in 2013 (Figure 2a; Figure 3). The soil management significantly $(p<0.01)$ influenced the APME activity. In particular, cover crops enhanced this enzymatic activity by $62 \%$, on average (Table 3). The APME is an extracellular enzyme involved in the P cycling and releasing $\mathrm{PO}_{4}{ }^{3-}$ from P-containing compounds. Thus, the improvement of its activity in the presence of cover crops may be extremely beneficial over time, in order to reduce the use of phosphatic fertilizers. A significant 
effect $(p<0.001)$ of the year on APME activity was also observed. In particular, higher enzymatic activity was measured in 2013 and 2014, but it seemed unrelated to the trend of MBC (Figure 3; Figure 5).

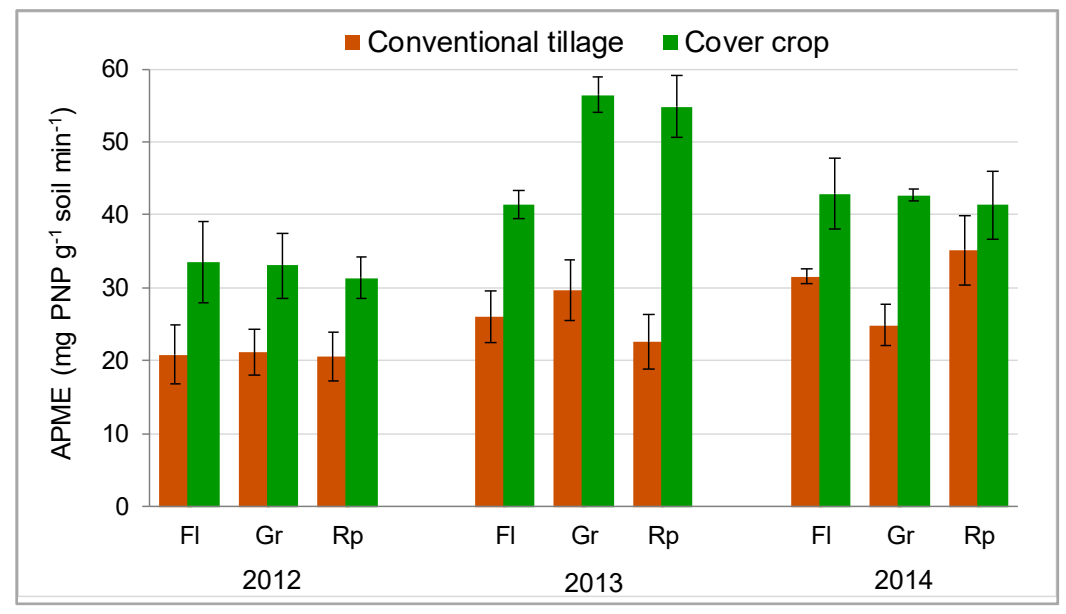

Figure 5. The trend of alkaline phosphomonoesterase activity (APME) in soil subjected to conventional tillage or cover crop during flowering $(\mathrm{Fl})$, fruit growth $(\mathrm{Gr})$ and ripening $(\mathrm{Rp})$ in the three years of experimentation. The bar on each column indicates the standard deviation $(n=3)$.

\subsection{Yield and Grape Qualitative Parameters}

Yield per vine and mean cluster weight were not influenced by the treatment, as recently reported in another mulched table grape vineyard [36], whereas they were significantly affected by the year and by the interaction treatment $\times$ year (Table 4 ). In 2012, cover crops reduced both yield and mean cluster weight, compared to the conventional tillage (Figure 6). Conversely, no effect was produced by the soil management system on these quantitative parameters in 2013 and 2014 (Figure 6). The reduction of crop yield in 2012 is attributable to the scarce summer rainfall (Figure 1), which intensified the competition for water between vines and fescue plants. It is widely recognized that the increased water consumption due to cover crops may exert a devigorating effect on vines, inhibiting their vegetative growth and the crop yield [10]. This effect may be emphasized under water deficit conditions and, if the irrigation is not properly balanced to compensate the excessive water loss, detrimental effects may be observed on the yield. Reductions in the vine yield are reported in a number of studies on the effects of cover crops on grape production [37-39]. Nevertheless, other studies find no relevant effects of cover crops on vine yield [40,41] and cluster weights [42], analogous to our study results in 2013 and 2014.

Table 4. Effect of the soil management system (treatment), growing season (year) and their interaction (treatment $\times$ year) on the quantitative and qualitative grape parameters.

\begin{tabular}{|c|c|c|c|c|c|c|c|c|c|c|c|}
\hline & Yield $^{1}$ & CW & BW & TSS & $\mathrm{pH}$ & TA & $F$ & DF & $\mathrm{C}^{*}$ & $\mathrm{~L}^{*}$ & $\mathbf{h}^{\circ}$ \\
\hline & $(\mathrm{kg})$ & (kg) & (g) & $\left({ }^{\circ}\right.$ Brix) & & $\left(\mathrm{g} \mathrm{L}^{-1}\right)$ & $(\mathrm{N})^{2}$ & (N) & \multicolumn{3}{|c|}{ (unitless) } \\
\hline \multicolumn{12}{|l|}{ Treatment } \\
\hline Conventional tillage & 27.62 & 1.08 & $11.26 \mathrm{a}$ & 16.99 & 3.57 & 4.79 & 2.53 & 8.4 & $9.24 \mathrm{a}$ & $43.99 \mathrm{a}$ & 110.44 \\
\hline Cover crop & 25.68 & 0.99 & $10.36 \mathrm{~b}$ & 17.32 & 3.47 & 4.92 & 2.35 & 7.9 & $8.69 \mathrm{~b}$ & $41.72 \mathrm{~b}$ & 111.32 \\
\hline \multicolumn{12}{|l|}{ Year } \\
\hline 2012 & $25.38 \mathrm{~b}$ & $0.97 \mathrm{~b}$ & $9.75 \mathrm{~b}$ & $18.10 \mathrm{a}$ & $3.30 \mathrm{~b}$ & $5.39 \mathrm{a}$ & $2.73 \mathrm{a}$ & $7.7 \mathrm{~b}$ & 8.83 & $43.04 \mathrm{a}$ & $107.49 \mathrm{~b}$ \\
\hline 2013 & $29.82 \mathrm{a}$ & $1.17 \mathrm{a}$ & $10.99 \mathrm{a}$ & $17.25 \mathrm{~b}$ & $3.66 \mathrm{a}$ & $4.26 \mathrm{c}$ & $2.71 \mathrm{a}$ & $8.1 \mathrm{~b}$ & 9.27 & $41.99 \mathrm{~b}$ & $111.30 \mathrm{a}$ \\
\hline 2014 & $24.75 \mathrm{~b}$ & $0.96 \mathrm{~b}$ & $11.69 \mathrm{a}$ & $16.12 \mathrm{c}$ & $3.60 \mathrm{a}$ & $4.92 \mathrm{~b}$ & $1.87 \mathrm{~b}$ & $8.6 \mathrm{a}$ & 8.80 & $43.54 \mathrm{a}$ & $113.86 \mathrm{a}$ \\
\hline \multicolumn{12}{|l|}{ Significance $^{3}$} \\
\hline Treatment $(\mathrm{T})$ & $0.2558^{\text {ns }}$ & $0.2057^{\mathrm{ns}}$ & $0.0222 *$ & $0.3143^{\mathrm{ns}}$ & $0.0818^{\text {ns }}$ & $0.2263^{\mathrm{ns}}$ & $0.2544^{\mathrm{ns}}$ & $0.2035^{\mathrm{ns}}$ & 0.0291 * & $0.0117 *$ & $0.4046^{\mathrm{ns}}$ \\
\hline Year $(Y)$ & 0.0142 * & $0.0076^{* *}$ & $0.0009 * * *$ & $0.0006^{* * *}$ & $0.0002 * * *$ & $0.0006^{* * *}$ & 0.0371 * & $0.0043 * *$ & $0.2313^{\text {ns }}$ & 0.0227 * & 0.0028 ** \\
\hline $\mathrm{T} \times \mathrm{Y}$ & $0.0058^{* *}$ & $0.0010^{* * *}$ & $0.0067 * *$ & $0.0442 *$ & $0.0993^{\mathrm{ns}}$ & $0.7361^{\mathrm{ns}}$ & $0.0742^{\text {ns }}$ & 0.0265 * & 0.1653 ns & $0.0425 *$ & $0.0897^{\text {ns }}$ \\
\hline
\end{tabular}

${ }^{1}$ Yield: yield per vine; CW: mean cluster weight; BW: mean berry weight; TSS: total soluble solids; TA: titratable acidity; F: berry firmness; DF: berry detachment force; $\mathrm{C}^{*}$ : chroma; $\mathrm{L}^{*}$ : lightness; $\mathrm{h}^{\circ}$ : hue. ${ }^{2} \mathrm{~N}$ : newton. ${ }^{3}$ Significant at $p<0.05\left(^{*}\right), p<0.01\left(^{* *}\right)$ and $\left.p<0.001{ }^{* * *}\right)$; not significant ${ }^{\left({ }^{\mathrm{ns}}\right)}$. Figures in columns followed by the same letter are not statistically different according to SNK test $(p<0.05)$. 


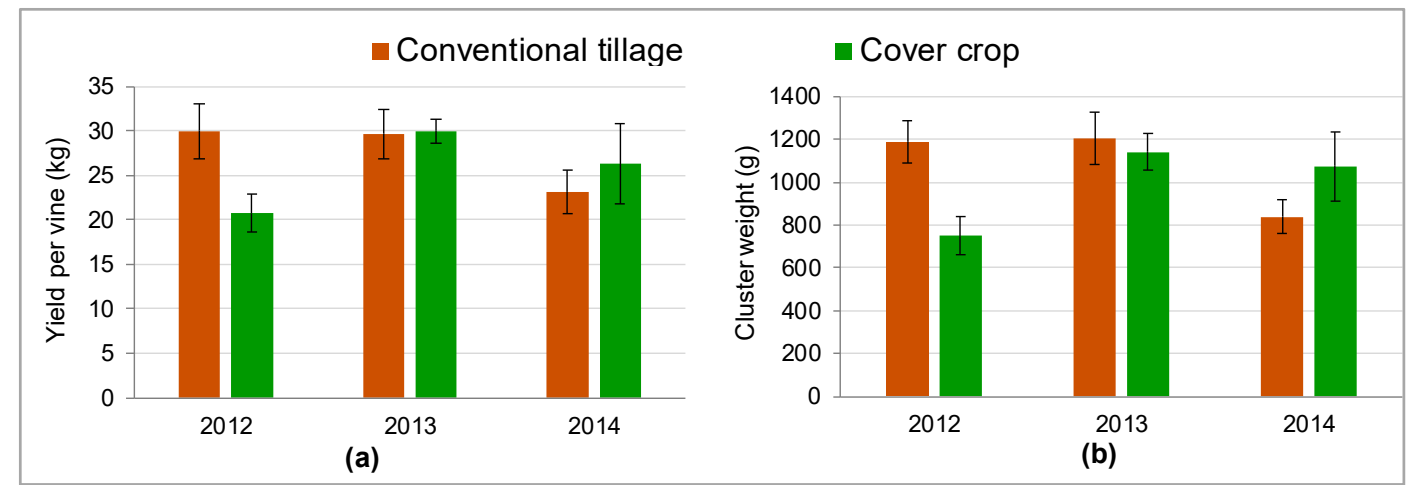

Figure 6. The trend of yield per vine (a) and mean cluster weight (b) under conventional tillage or cover crop during three years of experimentation. The bar on each column indicates the standard deviation $(n=3)$.

The berry weight was significantly affected by the soil treatment $(p<0.05)$, year $(p<0.001)$ and the interaction treatment $\times$ year $(p<0.01)$ (Table 4). A $21 \%$-reduction of the berry weight was observed in the presence of cover crops in 2012, but a partial and full recovery of the berry weight was observed in 2013 and 2014, respectively (Figure 7). In accordance with our study, Muscas et al. [39] observed that this parameter is influenced by the interaction between the soil management system and the year, and the effect of cover crops over the time may be sometimes positive (berry weight increase up to $20 \%$ ) and sometimes negative (with decreases down to 17\%), compared to the conventional tillage. The reduction of the berry weight in 2012, especially in the presence of cover crops, was ascribable to the drought conditions recorded during the summer, as mentioned earlier.

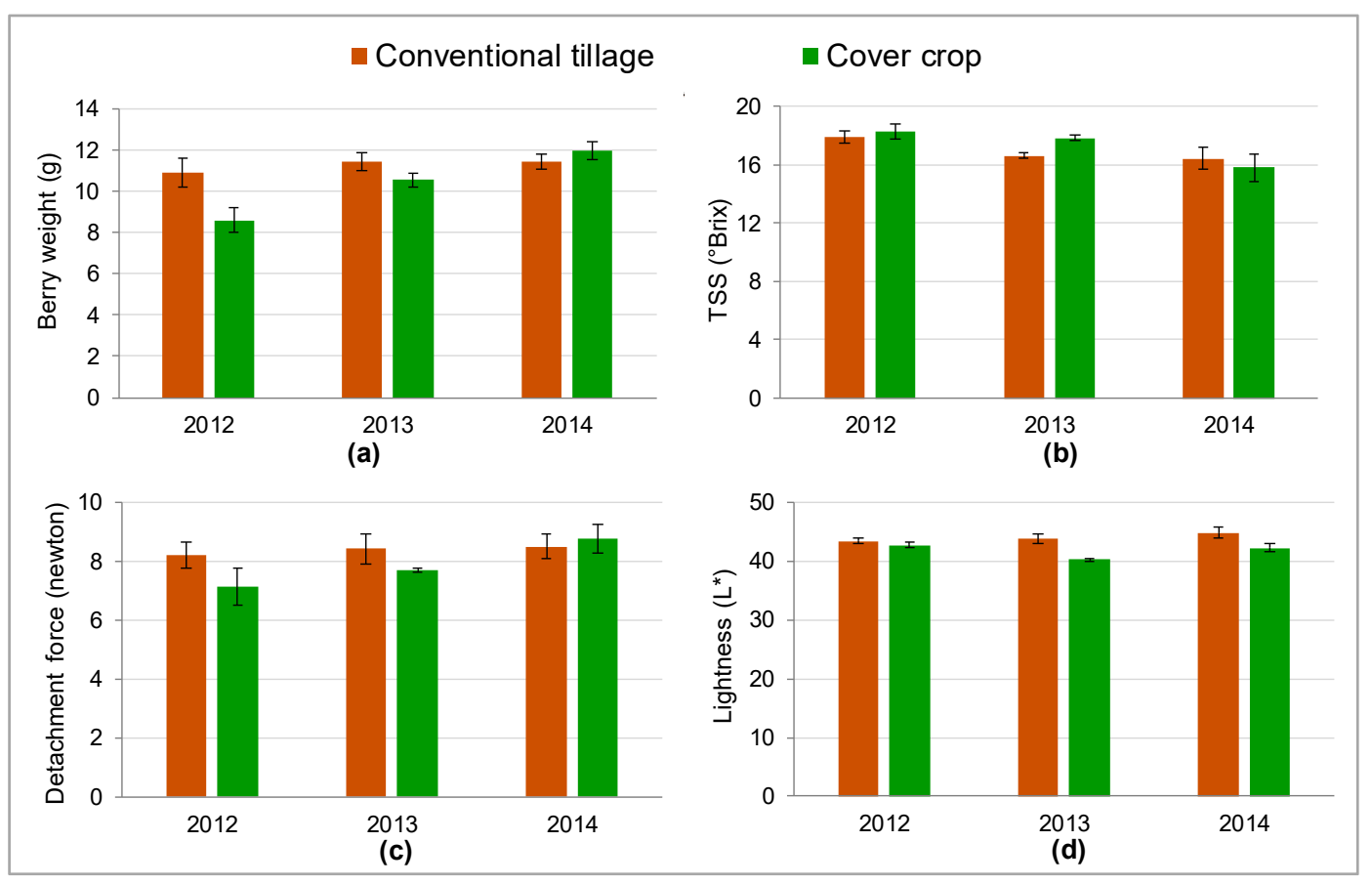

Figure 7. The trend of mean berry weight (a), total soluble solids (b), detachment force (c) and lightness (d) of grapes obtained under conventional tillage or cover crop during three years of experimentation. The bar on each column indicates the standard deviation $(n=3)$.

Among the grape qualitative properties, only the colorimetric parameters $\mathrm{C}^{*}$ and $\mathrm{L}^{*}$ were significantly influenced by the soil management system $(p<0.05)$ (Table 4$)$. Additionally, the total soluble solids, the detachment force and $\mathrm{L}^{*}$ were affected by the interaction treatment $\times$ year $(p<0.05)$ 
(Table 4). The remaining parameters were significantly affected only by the year $(p<0.001$ for $\mathrm{pH}$ and total acidity, $p<0.01$ for $\mathrm{h}^{\circ}$, and $p<0.05$ for firmness) (Table 4 ). It is widely recognized that the water and nutrient competition occurring under cover cropping may balance the vegetative and reproductive growth of vigorous vines, thus improving the berry composition [43]. Moreover, the reduced canopy density favors the cluster exposure to light and air, with positive consequences for the fruit quality and the control of pest attacks and diseases. In our study, the effects of cover crops on the grape quality were less evident, if compared with the effects on the soil quality. With respect to the conventional tillage, cover crops increased the total soluble solids in 2013, but had no effect in 2012 and 2014 (Figure 7). Similarly, a number of studies report that cover crops have positive or no effects on the soluble solid content of grapes [10,39]. The soluble solid content reached the highest values in 2012 (the driest season), concomitantly with the reduction of yield and berry weight (Figure 1, Table 4).

Cover crops slightly reduced the berry detachment force in 2012 and 2013, whereas any difference was observed between the two treatments in 2014 (Figure 7). Influence of different cover crops on the berry detachment force was reported by Tarricone et al. [25], however, they did not evaluate this parameter under conventional tillage, thus no comparison with our data can be done.

Chroma $\left(C^{*}\right)$ was significantly $(p<0.05)$ affected by the soil treatment, and appeared higher under the conventional soil tillage (Table 4$)$. Lightness $\left(L^{*}\right)$ was influenced by the interaction treatment $\times$ year, as well as by the treatment and the year $(p<0.05)$. In particular, this colorimetric parameter was reduced in the presence of cover crops in 2013 and 2014 (Figure 7). Overall, cover crops slightly modified the grape color, with a more saturated and vivid yellow in the conventional plot, although without compromising the production quality in the cover crop treatment. In fact, the grape colorimetric characteristics observed in the presence of cover crops were in accordance with values usually detected for cv "Italia" grapes produced in the south of Italy [44]. Data reported in the literature about the effect of cover crops on grape color mainly refer to red wine grape varieties [10,39], thus no comparison can be done with our data.

\section{Conclusions}

The present study demonstrates that the fescue cover crop strongly improves, in the short-term (three years), the soil chemical and microbiological properties of a table grape vineyard. In particular, the average increase of $136 \%$ of organic $\mathrm{C}$ in the cover crop treatment is impressive, considering the very low initial organic $C$ content of the soil $\left(2.6 \mathrm{~g} \mathrm{~kg}^{-1}\right)$. This enhanced $C$ sequestration, along with the increased total $\mathrm{N}$ content and root biomass (due to the absence of tillage passes), stimulates the soil microbial growth. The higher BGLU and APME activities measured in the presence of cover crops are indicative of a better nutrient cycling in soil, with potential advantages for the reduction of fertilization in the long-term. Results also reveal a joint influence of the soil treatment, growing season and phenological stage on the microbiological properties of soils, thus proving that the soil quality is driven by a combination of environmental, climatic and physiological factors. In the present study, cover crops have no influence on the yield parameters, except for the driest season (year 2012), when the high water competition between vines and fescue plants caused a relevant reduction of yield per vine, mean cluster weight and berry weight. Therefore, the use of a cover crop under semi-arid conditions is advantageous, provided that water depletion in the soil is adequately compensated by irrigation. The slight influence of cover crops on some grape qualitative parameters (color, total soluble content and detachment force), varying also over the years, demonstrates that the grape quality is scarcely affected by the soil management system in the short-term. Nevertheless, it cannot be excluded that the improved soil quality and functions caused by cover crops may also produce, in the long-term, an improvement of the production quality.

Author Contributions: Conceptualization M.S., C.E.G., G.N.M.; methodology, G.N.M., G.P., G.O.; data curation, C.E.G., A.M.S., M.C., G.F.; writing-original draft preparation, C.E.G.; writing-review and editing, C.E.G., G.N.M., A.M.S., G.F., M.C., M.S.; supervision, M.S. All authors have read and agreed to the published version of the manuscript. 
Funding: This research received no external funding.

Acknowledgments: Authors thank Nicola Carella and Antonio Mastropirro for the technical support given during the experimental work, and the farm "La Porta" of San Ferdinando di Puglia (Italy), where the experimentation was performed.

Conflicts of Interest: The authors declare no conflict of interest.

\section{References}

1. International Organisation of Vine and Wine (OIV). 2019 Statistical Report on World Vitiviniculture. 2019, p. 23. Available online: http://oiv.int/public/medias/6782/oiv-2019-statistical-report-on-world-vitiviniculture.pdf (accessed on 21 August 2020).

2. United States Department of Agriculture, Foreign Agricultural Service (USDA). Fresh Apples, Grapes, and Pears: World Markets and Trade. Available online: https://apps.fas.usda.gov/psdonline/circulars/fruit.pdf (accessed on 24 July 2020).

3. Wiesmeier, M.; Urbanski, L.; Hobley, E.U.; Lang, B.; Von Lützow, M.; Marín-Spiotta, E.; Van Wesemael, B.; Rabot, E.; Ließ, M.; Garcia-Franco, N.; et al. Soil organic carbon storage as a key function of soils-A review of drivers and indicators at various scales. Geoderma 2019, 333, 149-162. [CrossRef]

4. Doetterl, S.; Berhe, A.A.; Nadeu, E.; Wang, Z.; Sommer, M.; Fiener, P. Erosion, deposition and soil carbon: A review of process-level controls, experimental tools and models to address $\mathrm{C}$ cycling in dynamic landscapes. Earth-Science Rev. 2016, 154, 102-122. [CrossRef]

5. Guzmán, G.; Cabezas, J.M.; Sánchez-Cuesta, R.; Lora, Á.; Bauer, T.; Strauss, P.; Winter, S.; Zaller, J.G.; Gómez, J. A field evaluation of the impact of temporary cover crops on soil properties and vegetation communities in southern Spain vineyards. Agric. Ecosyst. Environ. 2019, 272, 135-145. [CrossRef]

6. Brunori, E.; Farina, R.; Biasi, R. Sustainable viticulture: The carbon-sink function of the vineyard agro-ecosystem. Agric. Ecosyst. Environ. 2016, 223, 10-21. [CrossRef]

7. Blanco-Canqui, H.; Shaver, T.M.; Lindquist, J.L.; Shapiro, C.A.; Elmore, R.W.; Francis, C.; Hergert, G.W. Cover Crops and Ecosystem Services: Insights from Studies in Temperate Soils. Agron. J. 2015, 107, 2449-2474. [CrossRef]

8. Bronick, C.; Lal, R. Soil structure and management: A review. Geoderma 2005, 124, 3-22. [CrossRef]

9. Ruiz-Colmenero, M.; Bienes, R.; Eldridge, D.; Marques, M. Vegetation cover reduces erosion and enhances soil organic carbon in a vineyard in the central Spain. Catena 2013, 104, 153-160. [CrossRef]

10. Guerra, B.; Steenwerth, K.L. Influence of Floor Management Technique on Grapevine Growth, Disease Pressure, and Juice and Wine Composition: A Review. Am. J. Enol. Vitic. 2011, 63, 149-164. [CrossRef]

11. Roldan, A.; Salinas-García, J.; Alguacil, M.; Diaz, E.; Caravaca, F. Soil enzyme activities suggest advantages of conservation tillage practices in sorghum cultivation under subtropical conditions. Geoderma 2005, 129, 178-185. [CrossRef]

12. Mijangos, I.; Perez, R.; Albizu, I.; Garbisu, C. Effects of fertilization and tillage on soil biological parameters. Enzym. Microb. Technol. 2006, 40, 100-106. [CrossRef]

13. Pandey, D.; Agrawal, S.B.; Bohra, J.S. Effects of conventional tillage and no tillage permutations on extracellular soil enzyme activities and microbial biomass under rice cultivation. Soil Tillage Res. 2014, 136, 51-60. [CrossRef]

14. de Andrade Barbosa, M.; de Sousa Ferraz, R.L.; Coutinho, E.L.M.; Coutinho Neto, A.M.; da Silva, M.S.; Fernandes, C.; Rigobelo, E.C. Multivariate analysis and modeling of soil quality indicators in long-term management systems. Sci. Total. Environ. 2019, 657, 457-465. [CrossRef]

15. Virto, I.; Imaz, M.J.; Fernandez-Ugalde, O.; Urrutia, I.; Enrique, A.; Bescansa, P. Soil quality evaluation following the implementation of permanent cover crops in semi-arid vineyards. Organic matter, physical and biological soil properties. Span. J. Agric. Res. 2012, 10, 1121. [CrossRef]

16. Peregrina, F.; Pérez-Álvarez, E.; García-Escudero, E. Soil microbiological properties and its stratification ratios for soil quality assessment under different cover crop management systems in a semiarid vineyard. J. Plant Nutr. Soil Sci. 2014, 177, 548-559. [CrossRef]

17. Okur, N.; Kayikcioglu, H.; Ates, F.; Yagmur, B. A comparison of soil quality and yield parameters under organic and conventional vineyard systems in Mediterranean conditions (West Turkey). Boil. Agric. Hortic. 2015, 32, 73-84. [CrossRef] 
18. Indorante, S.J.; Hammer, R.D.; Koenig, P.G.; Follmer, L.R. Particle-Size Analysis by a Modified Pipette Procedure. Soil Sci. Soc. Am. J. 1990, 54, 560-563. [CrossRef]

19. ISO 10693. Soil Quality—Determination of Carbonate Content_Volumetric Method; International Organization for Standardization: Genève, Switzerland, 1995.

20. Sparks, D.L. Methods of soil analysis: Chemical methods, Part 3; Sparks, D.L., Page, A.L., Helmke, P.A., Loeppert, R.H., Eds.; Soil Science Society of America, American Society of Agronomy: Madison, WI, USA, 1996.

21. Vance, E.; Brookes, P.; Jenkinson, D. An extraction method for measuring soil microbial biomass C. Soil Boil. Biochem. 1987, 19, 703-707. [CrossRef]

22. Eivazi, F.; Tabatabai, M. Factors affecting glucosidase and galactosidase activities in soils. Soil Boil. Biochem. 1990, 22, 891-897. [CrossRef]

23. Eivazi, F.; Tabatabai, M. Phosphatases in soils. Soil Boil. Biochem. 1977, 9, 167-172. [CrossRef]

24. Littell, R.C.; Milliken, G.A.; Stroup, W.W.; Wolfinger, R.D.; Schabenberger, O. SAS for Mixed Models, 2nd ed.; Jason, R., Ed.; SAS Institute Inc.: Cary, NC, USA, 2006.

25. Tarricone, L.; DeBiase, G.; Masi, G.; Gentilesco, G.; Montemurro, F. Cover Crops Affect Performance of Organic Scarlotta Seedless Table Grapes Under Plastic Film Covering in Southern Italy. Agronomy 2020, 10, 550. [CrossRef]

26. Fourie, J. Soil Management in the Breede River Valley Wine Grape Region, South Africa. 4. Organic Matter and Macro-nutrient Content of a Medium-textured Soil. South Afr. J. Enol. Vitic. 2016, 33, 105-114. [CrossRef]

27. Fourie, J.; Agenbag, G.; Louw, P. Cover Crop Management in a Sauvignon Blanc/Ramsey Vineyard in the Semi-Arid Olifants River Valley, South Africa. 3. Effect of Different Cover Crops and Cover Crop Management Practices on the Organic Matter and Macro-Nutrient Contents of a Sandy Soil. South Afr. J. Enol. Vitic. 2016, 28, 92-100. [CrossRef]

28. Dalal, R.C. Soil microbial biomass-what do the numbers really mean? Aust. J. Exp. Agric. 1998, 38, 649-665. [CrossRef]

29. Riches, D.; Porter, I.; Oliver, D.; Bramley, R.; Rawnsley, B.; Edwards, J.; White, R. Review: Soil biological properties as indicators of soil quality in Australian viticulture. Aust. J. Grape Wine Res. 2013, 19, 311-323. [CrossRef]

30. Gunapala, N.; Scow, K.M. Dynamics of soil microbial biomass and activity in conventional and organic farming systems. Soil Boil. Biochem. 1998, 30, 805-816. [CrossRef]

31. Torres, R.L.; Lloreda, M.D.L.F.; Gonzalez, P.J.; Garcia-Gutierrez, J.R.L.; Trujillo, P.B. Effect of soil management strategies on the characteristics of the grapevine root system in irrigated vineyards under semi-arid conditions. Aust. J. Grape Wine Res. 2018, 24, 439-449. [CrossRef]

32. Torres-Sánchez, R.; Ferrara, G.; Soto, F.; López, J.A.; Sanchez, F.; Mazzeo, A.; Pérez-Pastor, A.; Domingo, R. Effects of soil and climate in a table grape vineyard with cover crops. Irrigation management using sensors networks. Ciência e Técnica Vitivinícola 2017, 32, 72-81. [CrossRef]

33. Giacometti, C.; Demyan, M.S.; Cavani, L.; Marzadori, C.; Ciavatta, C.; Kandeler, E. Chemical and microbiological soil quality indicators and their potential to differentiate fertilization regimes in temperate agroecosystems. Appl. Soil Ecol. 2013, 64, 32-48. [CrossRef]

34. Jian, S.; Li, J.; Chen, J.; Wang, G.; Mayes, M.A.; Dzantor, K.E.; Hui, D.; Luo, Y. Soil extracellular enzyme activities, soil carbon and nitrogen storage under nitrogen fertilization: A meta-analysis. Soil Boil. Biochem. 2016, 101, 32-43. [CrossRef]

35. Burns, R. Enzyme activity in soil: Location and a possible role in microbial ecology. Soil Boil. Biochem. 1982, 14, 423-427. [CrossRef]

36. Tarantino, A.; Mazzeo, A.; Lopriore, G.; Disciglio, G.; Gagliardi, A.; Nuzzo, V.; Ferrara, G. Nutrients in clusters and leaves of Italian table grapes are affected by the use of cover crops in the vineyard. J. Berry Res. 2020, 10, 157-173. [CrossRef]

37. Carsoulle, J. L'enherbement permanent du vignoble. Influence sur la production viticole et son environment. Phytoma 1995, 478, 38-41.

38. Morlat, R.; Jacquet, A. Grapevine root system and soil characteristics in a vineyard maintained long-term with or without interrow sward. Am. J. Enol. Vitic. 2003, 54, 1-17.

39. Muscas, E.; Cocco, A.; Mercenaro, L.; Cabras, M.; Lentini, A.; Porqueddu, C.; Nieddu, G. Effects of vineyard floor cover crops on grapevine vigor, yield, and fruit quality, and the development of the vine mealybug under a Mediterranean climate. Agric. Ecosyst. Environ. 2017, 237, 203-212. [CrossRef] 
40. Baumgartner, K.; Steenwerth, K.L.; Veilleux, L. Cover-Crop Systems Affect Weed Communities in a California Vineyard. Weed Sci. 2008, 56, 596-605. [CrossRef]

41. Giese, G.; Velasco-Cruz, C.; Roberts, L.; Heitman, J.; Wolf, T.K. Complete vineyard floor cover crops favorably limit grapevine vegetative growth. Sci. Hortic. 2014, 170, 256-266. [CrossRef]

42. Sweet, R.M.; Schreiner, R.P. Alleyway cover crops have little influence on Pinot noir grapevines (Vitis vinifera L.) in two western Oregon vineyards. Am. J. Enol. Vitic. 2010, 61, 240-252.

43. Xi, Z.-M.; Tao, Y.-S.; Zhang, L.; Li, H. Impact of cover crops in vineyard on the aroma compounds of Vitis vinifera L. cv Cabernet Sauvignon wine. Food Chem. 2011, 127, 516-522. [CrossRef]

44. Ferrara, G.; Malerba, A.D.; Matarrese, A.M.S.; Mondelli, D.; Mazzeo, A. Nitrogen Distribution in Annual Growth of 'Italia' Table Grape Vines. Front. Plant Sci. 2018, 9, 871. [CrossRef]

(C) 2020 by the authors. Licensee MDPI, Basel, Switzerland. This article is an open access article distributed under the terms and conditions of the Creative Commons Attribution (CC BY) license (http://creativecommons.org/licenses/by/4.0/). 